\title{
Regular article \\ Identification of seed storage protein markers for drought tolerance in mungbean
}

\author{
Swapan K. Tripathy*, P.Mohanty, M. Jena, Sasmita Dash , D. Lenka, D. \\ Mishra, P. K. Nayak, D. Swain, Rajesh Ranjan, K. Pradhan, N. Senapati, \\ P. M. Mohapatra and G. B. Dash \\ In vitro Culture \& Molecular Breeding Laboratory, Department of Agricultural Biotechnology, \\ College of Agriculture, OUAT, Bhubaneswar-751003, India \\ *Corresponding Author Email:swapankumartripathy@gmail.com
}

A set of 292 mungbean germplasm accessions including 62 popularly adapted local land races and two wild forms (Vigna radiata var. sublobata), important breeding lines and standard ruling varieties were screened for drought stress tolerance at seedling stage. Eight genotypes e.g., C. No. 35, OUM 14-1, OUM 49-2, Pusa 9072, OM 99-3, Banapur local B, Nipania munga, Kalamunga 1-A) have been identified to possess drought tolerance. Globulin seed storage protein profiling was carried out in 19 selected mungbean genotypes comprising eight drought tolerant, seven drought sensitive, two wild forms of mungbean (TCR 20 and TCR 213) and two standard checks (LGG 460 and T 2-1) to explore differentially expressed polypeptides. Seed protein profiles revealed 15 scorable polypeptide bands with molecular weights ranging from 10.0 to $102.2 \mathrm{kD}$.A specific $12.8 \mathrm{kD}$ polypeptide band was present in all above drought tolerant test genotypes including the wild accession TCR 20. Such a polypeptide band may serve as useful biochemical marker for identification of drought tolerant genotypes in mungbean.

Key words: Genetic diversity, seed storage protein profile, wild and cultivated Vigna radiata.

Mungbean (Vigna radiata (L.) wilczek, $2 n=22)$ is an important short duration pulse crop of India and Odisha in particular. Generally, pulses are very susceptible to water stress (Agele et al. 2006). Unfortunately, available mungbean varieties lack satisfactory level of drought tolerance and at present drought tolerant high yielding varieties are not available in this crop. The extent and rate of progress in improving drought stress tolerance through conventional breeding is limited owing to its multigenic nature and complex mechanism involved (Athar and Ashraf 2009). Therefore, searching for candidate genes conferring drought tolerance could be a practical proposition. In this context, screening of a large collection of germplasm lines including wild accessions can pave the way for identification of tolerant genotypes. Drought tolerant genotypes are reported to accumulate stress related proteins particularly dehydrins which are synthesized in mature seeds. Garnczarska et al. (2008) and Tolleter et al. (2007) revealed accumulation of dehydrins following seed desiccation in pea. Besides, Russouw et al. (1995) isolated and characterized an $11 \mathrm{kD}$ LEA (late embryogenic abundant) like-protein from embryonic axes 
during development of pea seeds. Besides, a few low molecular weight polypeptides associated with responses to water deficit were observed at $14.2 \mathrm{kD}$ for a barley dehydrins (Close et al. 1989), 22kD for Lathyrus sativus (Tyagi et al. 1995), Brassica napus and Arabidopsis thaliana (Marie-Pierre et al. 1992, Yamaguchi-Shinozaki and Shinozaki 1993), a 26kD osmotin in tobacco (Singh et al. 1987 ) and $23 \mathrm{kD}$ polypeptide in rice (Rao et al. 1993). Polypeptide banding pattern has been also effectively employed by Afiah and Rashed (2000) and Sinha et al. (1999) for isolation of plants under calcareous soil in mungbean and for tolerance to salt stress in Lathyrus satious (L.) respectively.

Polypeptide markers detected through seed protein profiling are known to be quite stable as compared to soluble proteins and isozymes (Dutta and Mallick 2012). Seed storage protein profiling has been employed for elucidation of evolution and phylogenetic relationships (Naik 1998, Kole et al. 2000), hybrid selection, characterization and identification of varieties (Tripathy et al.2010a, b, c). Panigrahi et al. (2001) detected species specific seed protein markers for differentiation of Cajanus cajan fromC. cajanifolius. Similarly, Abdellati et al. (2012) differentiated drought tolerant varieties from susceptible genotypes of faba bean by presence of some specific seed storage protein bands. Thus, seed storage protein finger printing assumes immense value for polypeptide profiling. In the present investigation, the authors attempted to unravel polypeptides markers associated with drought tolerance using seed storage protein profiling ofmungbean.

\section{Materials and Methods}

A large collection of 292 mungbean genotypes were phenotyped for status of drought tolerance under water stress at seedling stage. Nineteen selected mungbean genotypes comprising drought tolerant and sensitive checks were field tested under water deficit. Globulin seed storage protein fraction of matured seeds of each of these genotypes was extracted with $0.5 \mathrm{M} \mathrm{NaCl}$, denatured with an equal volume of cracking buffer (0.125M Tris $\mathrm{HCl} \mathrm{pH} 6.8,4 \%$ SDS, $20 \%$ glycerol, $\quad 10 \%$ 2-mercaptoethanol, $0.1 \%$ Bromophenol blue) at $80^{\circ} \mathrm{C}$ in hot water bath. Seed proteins were analysed simultaneously by running two gels at a time in a vertical slab gel $(12.5 \%$ polyacrylamide gel) at constant current of $60 \mathrm{~mA}(2.5 \mathrm{~mA}$ per lane for two gels run each time) for four hours following Laemmli (1970) with minor modifications. Reproducibility was confirmed by minimum of two repeats of each run of sodium dodecyl polyacrylamide gel electrophoresis (SDS-PAGE) under similar electrophoretic conditions. After electrophoresis, gels were stained with $0.125 \% \mathrm{w} / \mathrm{v}$ coomassie brilliant blue R 250, $50 \% \mathrm{v} / \mathrm{v}$ methanol, and $10 \% \mathrm{v} / \mathrm{v}$ glacial acetic acid for four hours with intermittent shaking followed by destaining overnight in 50\% methanol and 10\% glacial acetic acid; and finally, several washings with $5 \%$ methanol and $7 \%$ glacial acetic acid. The molecular weights of the dissociated polypeptides were determined by using molecular weight marker with known molecular weights i.e., bovine plasma albumin, (66kD), egg albumin (45kD), glyceraldehydes-3-phosphate dehydrogenase $(34.7 \mathrm{kD})$ and bovine pancreas tripsinogen $(24 \mathrm{kD})$. Differentially expressed unique polypeptide bands were noted to find relationship with drought tolerance.

\section{Results and Discussion}

Screening techniques for drought tolerance in legumes has been widely reported (Singh et al. 1999, Dutta and Bera 2008). Singh et al. (1999) used wooden box lined with polythene sheets and filled with soils and sand mixture (1:1) for screening cowpea genotypes under drought stress. Dutta and Bera (2008), however, adopted artificial screening for drought tolerance using polyethylene glycol (PEG) in mungbean. In the present pursuit, 
ten day old seedlings of a large collection of 292 mungbean accessions grown in plastic cups, were exposed to moisture stress by watering with a gap of one, three and five days and then left for a week without irrigation. The drought tolerance screening was repeated thrice until all plants of the sensitive variety were died. Eight genotypes e.g., C. No. 35, OUM 14-1, OUM 49-2, Pusa 9072, OM 99-3, Banapur local B, Nipaniamunga, Kalamunga 1-A (Fig. 1 \& 2) were scored drought tolerant (score 0-1) in 09 scale. However, Dutta and Bera (2008) identified drought tolerant genotypes based on tolerance index (ratio of dry weight of seedling under stress to dry weight of seedling under control condition) and Singh et al. (1999) stressed on percentage permanent wilting and percentage plant recovery after resume of watering as useful criteria for genotypic assessment of drought tolerance. The candidate genotypes identified above along with seven drought sensitive (DS), two wild forms (Vigna radiata var. sublobata: TCR 20 and TCR 213) and two standard checks (LGG 460 and T 2-1) were subjected to seed storage protein profiling to identify marker(s), if any, associated with drought tolerance.

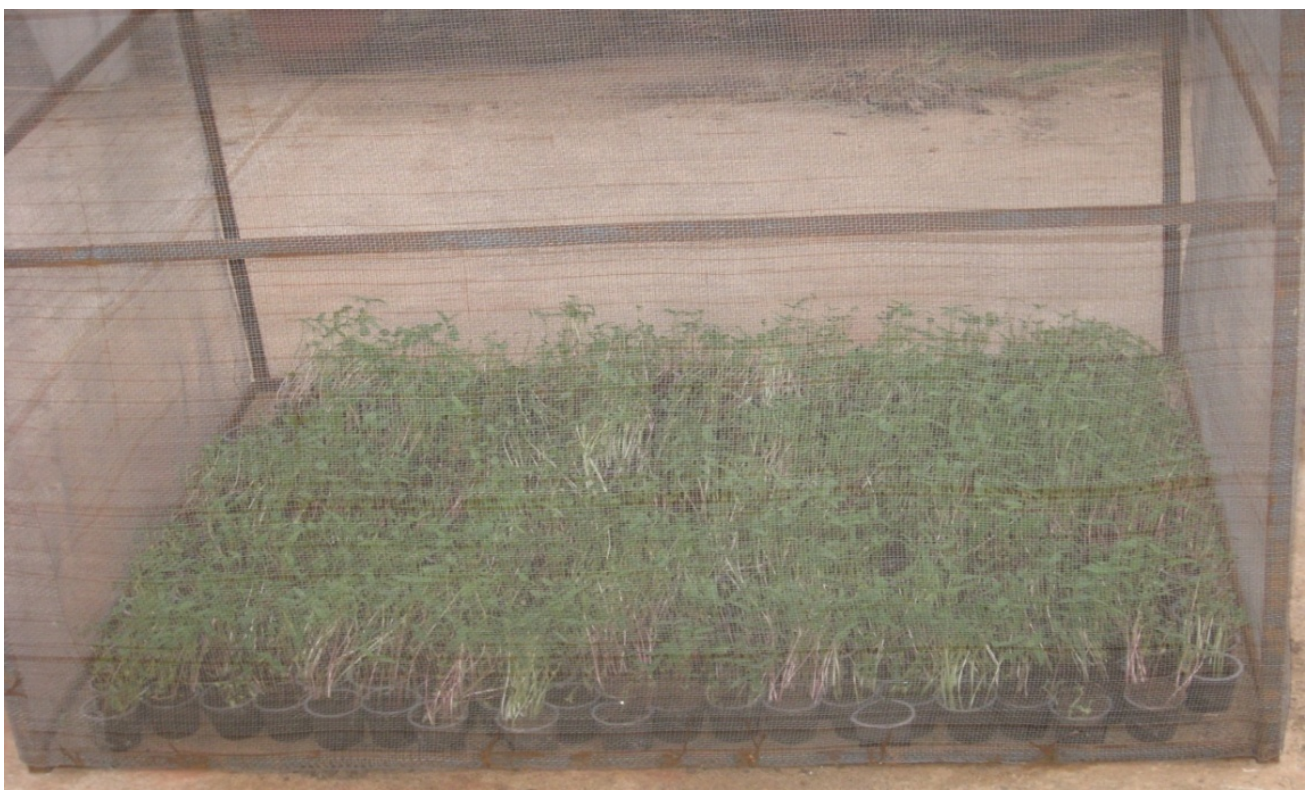

Fig 1. Drought tolerance screening of mungbean germplasm lines (normal seedlings 10 days after sowing).

The SDS-PAGE revealed altogether 15scorable polypeptide bands with molecular weight ranging from 10.0 to $102.2 \mathrm{kD}$ (Fig 3). A minimum six polypeptide bands were observed in case of Nipaniamunga, TCR 213 and T 2-1 while, it was as high as 13 in C. No. 35 and OUM 14-1. The importance of protein profiling has long been acknowledged in plant abiotic stress studies. In the present investigation, a polypeptide bandat $60.5 \mathrm{kD}$ was specifically absent in the drought resistant local land race Nipaniamunga, but present in all other test genotypes (Fig 3). Such a genotype barely expressed six globulin polypeptide bands including two monomorphic bands at $102.2 \mathrm{kD}$ and $53.7 \mathrm{kD}$ in mature seeds as compared to 10-13 bands in other drought resistant genotypes. Absence of the above polypeptide band in this drought resistant genotype could be due to down regulation of a kind of stress inducible protein under drought stress. Jiang et al. (1997) have shown that the promoter regions of storage protein genes contain the 
information for their down regulation during seed desiccation. Deletion or mutation in regulatory and / or structural genes may lead to failure of protein expression (Brown et al. 1981). A few differentially expressed polypeptide(s) were reported to be present only in the susceptible genotypes for YMV resistance in mungbean (Patnaik and Kole 2002) and green leafhopper resistance in rice
(Padmavathi et al. 1999). In contrast, Chand and Kole (2002) identified a polypeptide band at $R m 0.790$ in resistant genotypes and another band at $R m 0.781$ unique to susceptible genotypes of mungbean. Iqbal et al. (2005), however, observed no relationship between SDS-PAGE based seed storage protein markers with varietal resistance to Ascochita blight in chickpea.

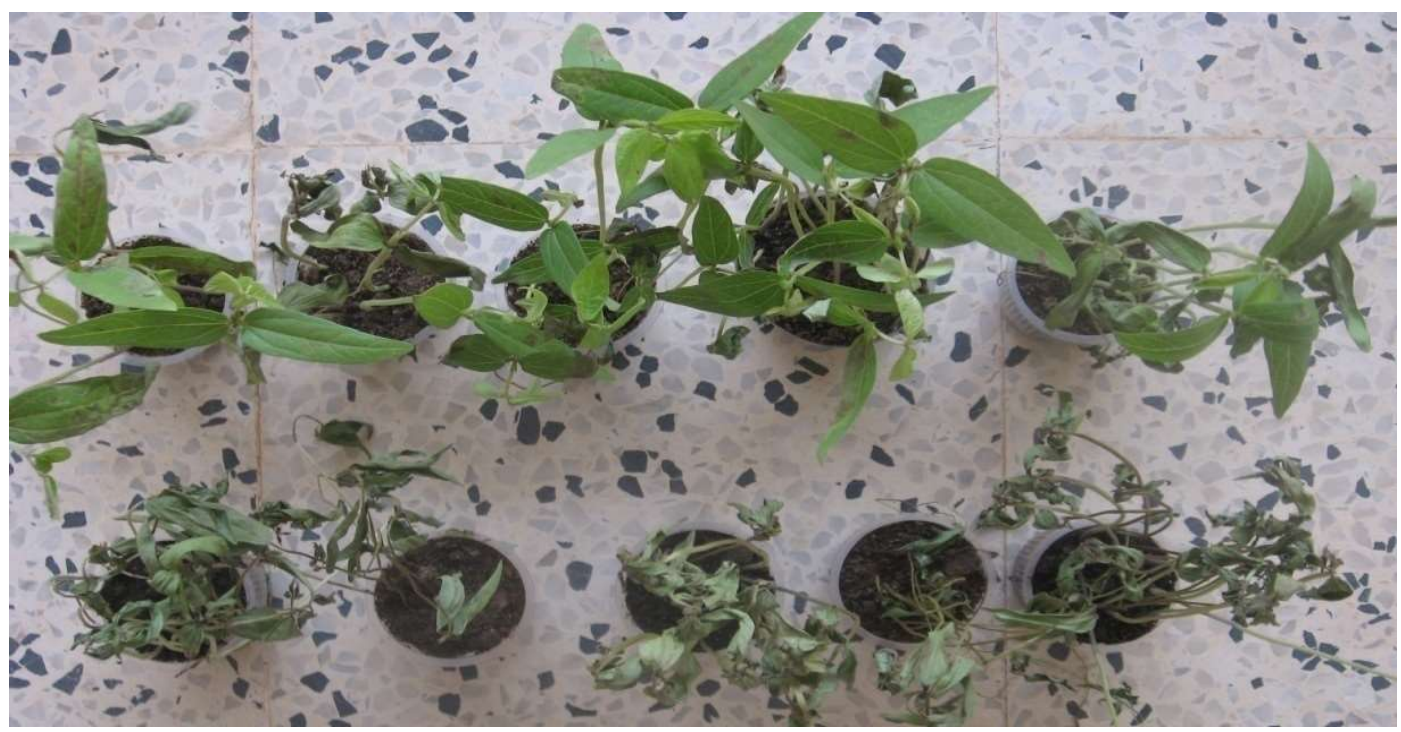

Fig 2. Drought stress resistant genotypes (top row- left to right): OM 99-3, Nipaniamunga, Kalamunga 1A, OUM 14-1, Banapur local B; Drought sensitive genotypes (bottom row-left to right): OUM 13-2, OBGG 183, PMB 9, Pusa 2072 and T 7-7 Sel.2

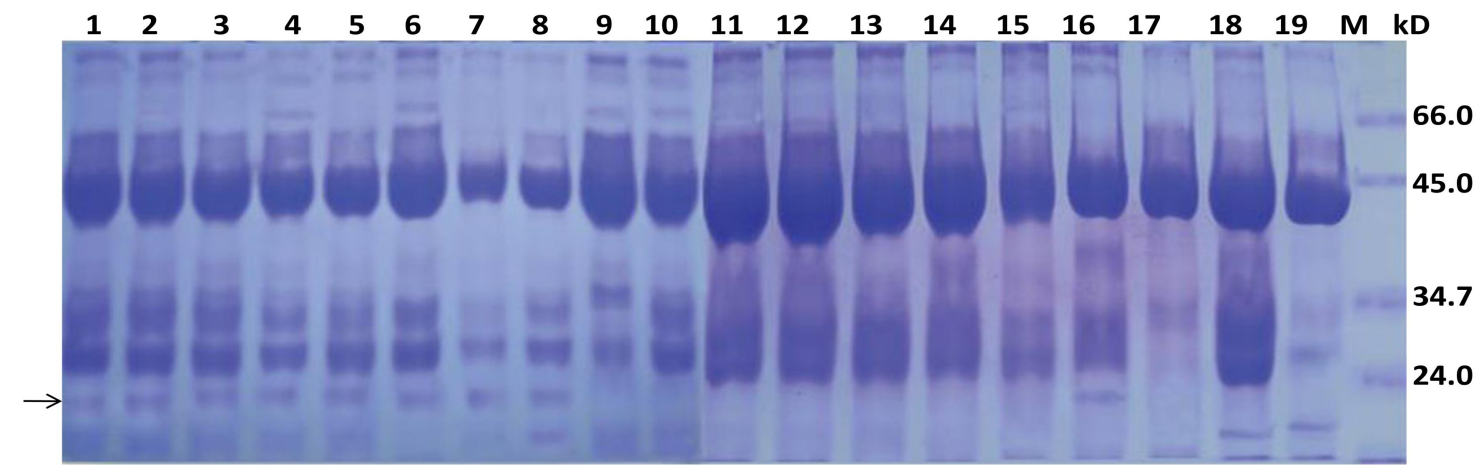

Fig. 3.SDS-PAGE polypeptide profile of globulin seed storage protein fraction of 19 mungbean genotypes, Lane 1-8 (drought tolerant): C. No. 35, OUM 14-1, OUM 49-2, Pusa 9072, OM 99-3, Banapur local B, Nipaniamunga, Kalamunga 1-A; Lane 9-15(drought sensitive): T 7-10 sel. 3, OUM 13-2, OBGG 183, PMB 9, Pusa 2072, T 7-7 Sel.2, Nayagarh Local-C; Lane 16\& 17(wild mungbean): TCR-20, TCR 213; Lane 18 \& 19(standard checks): LGG 460, T 2-1. 
Table 1. Electrophoretic (SDS-PAGE) polypeptide banding patterns of Globulin seed storage protein of 19 selected genotypes.

\begin{tabular}{|c|c|c|c|c|c|c|c|c|c|c|c|c|c|c|c|c|c|c|c|}
\hline & $\begin{array}{l}\text { n } \\
\dot{0} \\
Z \\
Z\end{array}$ & $\sum_{0}^{I}$ & 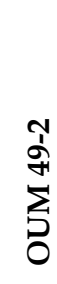 & 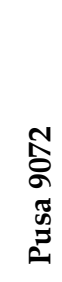 & $\begin{array}{l}\sum_{0}^{2} \\
\sum_{0}^{2}\end{array}$ & 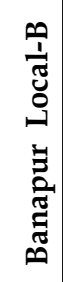 & 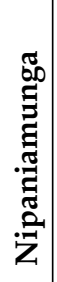 & 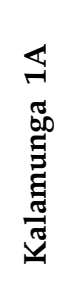 & 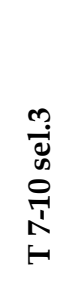 & 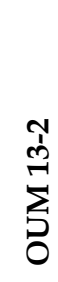 & 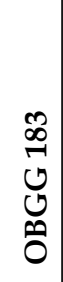 & $\sum_{i=1}^{n}$ & 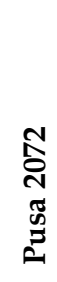 & 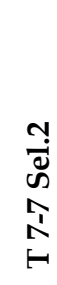 & 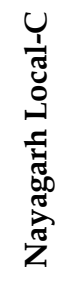 & 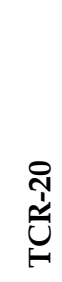 & $\begin{array}{l}\stackrel{m}{N} \\
\tilde{U} \\
\end{array}$ & \begin{tabular}{l}
8 \\
\multirow{H}{1}{} \\
0 \\
0 \\
0
\end{tabular} & $\stackrel{+}{\text { N }}$ \\
\hline $\mathscr{\infty}$ & 1 & 2 & 3 & 4 & 5 & 6 & 7 & 8 & 9 & 10 & 11 & 12 & 13 & 14 & 15 & 16 & 17 & 18 & 19 \\
\hline$B_{1}(102.2 k d)$ & 1 & 1 & 1 & 1 & 1 & 1 & 1 & 1 & 1 & 1 & 1 & 1 & 1 & 1 & 1 & 1 & 1 & 1 & 1 \\
\hline$B_{2}(94.0 k d)$ & 1 & 1 & 1 & 1 & 1 & 1 & 1 & 0 & 1 & 1 & 1 & 1 & 1 & 1 & 1 & 1 & 0 & 1 & 0 \\
\hline$B_{3}(85.9 k d)$ & 1 & 1 & 0 & 0 & 0 & 0 & 0 & 0 & 0 & 0 & 1 & 1 & 1 & 0 & 0 & 0 & 0 & 0 & 0 \\
\hline$B_{4}(81.2 k d)$ & 1 & 1 & 0 & 1 & 0 & 1 & 0 & 0 & 1 & 1 & 1 & 1 & 1 & 0 & 1 & 0 & 0 & 1 & 0 \\
\hline$B_{5}(64.0 \mathrm{kd})$ & 1 & 1 & 1 & 1 & 1 & 1 & 0 & 1 & 1 & 1 & 1 & 1 & 1 & 1 & 1 & 0 & 1 & 0 & 0 \\
\hline$B_{6}(60.5 k d)$ & 1 & 1 & 1 & 1 & 1 & 1 & 0 & 1 & 1 & 1 & 1 & 1 & 1 & 1 & 1 & 1 & 1 & 1 & 1 \\
\hline$B_{7}(53.7 k d)$ & 1 & 1 & 1 & 1 & 1 & 1 & 1 & 1 & 1 & 1 & 1 & 1 & 1 & 1 & 1 & 1 & 1 & 1 & 1 \\
\hline$B_{8}(50.7 k d)$ & 0 & 0 & 0 & 0 & 0 & 0 & 0 & 0 & 0 & 0 & 0 & 0 & 0 & 0 & 0 & 1 & 0 & 1 & 0 \\
\hline$B_{9}(45.8 \mathrm{kd})$ & 0 & 0 & 0 & 0 & 0 & 0 & 0 & 0 & 0 & 0 & 0 & 0 & 0 & 0 & 0 & 1 & 0 & 1 & 0 \\
\hline$B_{10}(40.0 k d)$ & 1 & 1 & 1 & 1 & 1 & 1 & 0 & 1 & 1 & 1 & 1 & 1 & 1 & 1 & 1 & 0 & 0 & 1 & 0 \\
\hline$B_{11}(38.1 k d)$ & 1 & 1 & 1 & 1 & 1 & 0 & 0 & 1 & 1 & 1 & 1 & 1 & 1 & 1 & 1 & 1 & 1 & 1 & 1 \\
\hline$B_{12}(35.6 k d)$ & 1 & 1 & 1 & 1 & 1 & 1 & 1 & 1 & 0 & 1 & 1 & 1 & 1 & 1 & 1 & 1 & 1 & 1 & 1 \\
\hline$B_{13}(29.0 k d)$ & 1 & 1 & 1 & 1 & 1 & 1 & 1 & 1 & 1 & 1 & 1 & 1 & 1 & 1 & 1 & 1 & 0 & 1 & 0 \\
\hline$B_{14}(12.8 k d)$ & 1 & 1 & 1 & 1 & 1 & 1 & 1 & 1 & 0 & 0 & 0 & 0 & 0 & 0 & 0 & 1 & 0 & 0 & 0 \\
\hline$B_{15}(10.0 k d)$ & 1 & 1 & 1 & 1 & 1 & 0 & 0 & 1 & 1 & 1 & 0 & 0 & 1 & 0 & 0 & 0 & 0 & 1 & 1 \\
\hline Total & 13 & 13 & 11 & 12 & 11 & 10 & 6 & 10 & 10 & 11 & 11 & 11 & 12 & 9 & 10 & 10 & 6 & 12 & 6 \\
\hline
\end{tabular}

A number of different proteins usually accumulate in mature seeds to stabilize and protect cellular structures during dehydration. These include some members of the LEA supergene family (Ingram and Bartels 1996) and heat shock proteins (HSPs) (Wehmeyer and Vierling 2000). Magnetic resonance imaging (MRI) can visualize accumulation of dehydrin proteins in the provascular tissue of both the maturing seed embryo axes and cotyledon whichevidenced involvement of dehydrins in promoting water influx into the vascular bundles. Among 13 polymorphic globulin polypeptide bands examined in the present set of drought resistant and drought sensitive genotypes; a specific polypeptide band at approximately $12.8 \mathrm{kD}$ (Fig 3, marked by arrow) was present in all erstwhile mentioned eight drought tolerant test genotypes including the wild accession TCR 20. This globulin protein fraction might be accumulated upon dehydration during seed maturation in the tolerant genotypes grown under drought stress. The physiological implication of this polypeptide expression only in the resistant genotypes; and the strength of linkage of the loci controlling the 
polypeptide $(12.8 \mathrm{kD})$ and tolerance to drought stress is not known. However, identification of such drought stress related responses of mungbean cultivars in the mature seeds may provide marker(s) for selection in breeding programme. Besides, this approach was also used to screen YMV resistant genotypes in mungbean (Pattnaik and Kole 2002).A LEA like-protein has been isolated with molecular weight $11 \mathrm{kD}$ in embryonic axes of pea seeds (Russouw et al. 1995).

\section{References}

Abdellati KF, Absawy EAE, Zakaria AM. 2012. Drought stress tolerance of faba bean as studied by morphological traits and seed storage protein pattern. J. Pl. Studies 1(2): 47-54.

Afiah SAN, Rashed NAK. 2000. Induced $\mathrm{M}_{3}$ tolerant mutants of mungbean to calcareous soil on the basis of polypeptide sub-units. Desert Inst. Bull, Egypt, 50(2): 309-324.

Brown JWS, Ma Y, Bliss FA, Hall TC. 1981. Genetic variation in the subunits of globulin 1 storage protein of frenchbean. Theor. Appl. Genet. 59: 83-88.

Chand S, Kole C. 2002. Protein markers for screening of CLS resistant mungbean (Vignaradiata

(L.)Wilczek) genotypes.Indian J. Genet. 62(4): 340-341.

Close TJ, Kortt AA, Chandler PM. 1989. A cDNA-based comparison of dehydrationinduced proteins (dehydrins) in barley and corn. Pl. Mol. Biol. 13: 95-108.

Dutta S, Mallick SK. 2012. Studies on genetic diversity of mungbean cultivars using polypeptide banding pattern polymorphism (PBPP) markers. Int. J. Life Sci. 1 (3): 56-58.

Jiang L, Downing WL, Baszczynski CL, Kermode AR. 1997. The 5' -flanking regions of vicilin and napin storage protein genes are down-regulated by desiccation in transgenic tobacco. Plant Physiol. 107: 1439-49.
Iqbal SM, Ghafoor A, Ayub N. 2005. Relationship between SDS-PAGE markers and Ascochyta blight in chickpea. Pak. J. Bot. 37(1): 87-96.

Ingram J, Bartels D. 1996. The molecular basis of dehydration tolerance in plants.Annu. Rev. Plant Physiol. Plant Mol. Biol. 47: 377-403.

Kole C, Panigrahi J, Patnaik A. 2000. Vigna glabrescens is a natural polyploidy of Vigna radiata and $V$. umbellata: An evidence from seed albumin electrophoresis (Abstract). In: National Symposium on Biotechnology for Sustainability in Agriculture, G. B. Pant University of Agriculture\& Technology, Pantnagar, India, p. 129.

Laemmli UK.1970. Cleavage of structural protein during the assembly of the read of bacteriophage. Nature 227: 680-685.

Marie-Pierre R, Nicole V, Marc S, Jean Claude H, Jean Claude P, de Vienne D. 1992. Characterization of a novel protein induced by progressive or rapid drought and salinity in Brassica napus leaves.Plant Physiol. 100: 1486-1493.

Naik BS. 1998. Genetic characterization of cultivars and seed protein in mungbean. Ph.D. Thesis, Utkal Univ., Vani Vihar, Bhubaneswar, India, p: 5-85.

Padmavathi G, Kole C, Siddiq EA.1999.Detection of protein markers for identification of rice genotypes resistant to green leafhopper.Indian J. Genet.59: 417421.

Panigrahi J, Patnaik SN, Kole C. 2001. Detection of species specific protein markers for Cajanus cajan and C. cajanifolius. Indian J. Genet. 61(3): 223-225.

Patnaik J, Kole C. 2002. Detection of a protein marker for screening of MYMV resistant mungbean genotypes.Indian J. Genet. 62(1): 77-78.

Rao AH, Karunasree B, and Reddy AR. 1993. Water stress-responsive $23 \mathrm{kDa}$ polypeptide from rice seedlings is boiling stable and is related to the RAB16 family of proteins. J. Plant Physiol. 142:88-93. 
Russouw PS, FarrantJ, Brandt W, Maeder D, Lindsey GG. 1995.Isolation and characterization of a heat-soluble protein from pea (Pisum sativum) embryos. Seed Sci. Res. 5: 137-144

Singh NK, Bracker CA, Hasegawa, Handa AK, Buckel S, Hermodson MA, Pfankoch ED, Regnier FE, Bresson RA. 1987. Characterization of osmotin: a thaumatinlike protein associated with osmotic adaptation in plant cells. Plant Physiol. 85(2): 529-536.

Singh BB, Mai-Kodomi Y, Terao T. 1999.A simple screening method for drought tolerance in cowpea. Indian J. Genet.59(2): 211-220.

Sinha KM, Archana Sachdev, Johari RP, Mehta SL. 1999. Stress induced polypeptides in Lathyrus sativus L. Plant Biochem. Biotech. 8: 47-51.

Tolleter D, Jaquinod M, Mangavel C, Passirani C, Saulnier P, Manon S, Teyssier E, Payet N, Avelange-Macherel $\mathrm{MH}$, Macherel D. 2007. Structure and function of a mitochondrial late embryogenesis abundant protein are revealed by desiccation. Plant Cell 19: 1580-1589.

Tripathy SK, Sardar SS., Lenka D, Sahoo S. 2010a.Genetic diversity of mungbean (Vigna radiata (L.)Wilczek) genotypes based on SDS-PAGE of albumin seed storage protein. Legume Res. 33: 54-57.

Tripathy SK, Sardar SS, Mishra DR Sahoo S. 2010b. Genetic diversity of mungbean (Vigna radiata (L.)Wilczek) genotypes based on SDS-PAGE of globulin seed storage protein. Environ. \& Eco. 28: 17981800.

Tripathy SK, Sardar SS, Mishra PK. 2010c. Analysis of seed storage protein pattern: A method for studying genetic variation and diversity among Vigna genotypes. Indian J.Genet. 70: 140-144.

Tyagi A, Santha IM, Mehta SL. 1995. Molecular response to water stress in Lathyrus sativus. J. Plant Biochem. 4: 47-49.

Wehmeyer N, Vierling E. 2000. The expression of small heat shock proteins in seeds responds to discrete developmental signals and suggests a general protective role in desiccation tolerance. Plant Physiol. 122: 1099-1108.

Yamaguchi-Shinozaki K, Shinozaki K. 1993.The plant hormone abscisic acid mediates the drought-induced expression but not the seed-specific expression of $\mathrm{rd22}$, a gene responsive to dehydration stress in Arabidopsis thaliana. Mol. Gen. Genet. 238: 17-25. 